\title{
The pollution load of wastewater and the performance of the sewage treatment plant of Skhirat city
}

\author{
Mehdi Bouhafa $^{1}$, Omar El Rhaouat ${ }^{2}$, Mostapha Lakhlifi $^{2}$, Sakina Belhamidi ${ }^{1}$, Azzedine El Midaoui ${ }^{1}$, and Fatima El Hannouni $^{1}$ \\ ${ }^{1}$ Laboratory of separation processes. Department of Chemistry, Faculty of Science, University Ibn Tofail. P. O. B: 133, 14000, \\ Kenitra, Morocco. \\ ${ }^{2}$ Laboratory of Agro-physiology, Biotechnology, Environment and Quality, Faculty of Science, University Ibn Tofail. P. O. B: 133, \\ 14000, Kenitra, Morocco.
}

\begin{abstract}
The Sewage Treatment Plant (STEP) based on Skhirat City receive on average an important volume of wastewater (about $66473 \mathrm{~m} 3$ with a flow of $2173.56 \mathrm{~m} 3 / \mathrm{day}$ ). The aim of this research is to evaluate the pollutant load of wastewater and the performances of the sewage treatment plant of Skhirat city in treating domestic wastewater. Sampling was carried out on the level of the entry of sewage treatment plant with a monthly rate. The analyses were carried at the laboratory with the cubic measure of wastewater received by the sewage treatment plant. The results show that the CODe/BOD5e ratio of 2.08, which makes it possible to confirm the normal state of the station in biological treatment since the ratio is lower than three. The results showed that the rate of the Chemical Oxygen Demand (COD), Biochemical Oxygen Demand (BOD5) and the Suspended Matter (SM) respectively it's of the order $87,4 \%, 90,68 \%$ and $79,50 \%$. Globally, the results of the investigation revealed by the unilateral test Student, that this difference between the entry and the exit of the station which significant by $p$-value calculated is lower than the level of significance alpha $=0,05$.
\end{abstract}

\section{Introduction}

In recent decades, Morocco has adopted a strategy that is moving towards the management of water resources with the implementation of a national sanitation program in order to generalize almost all connections whether urban or rural environment by minimizing any environmental impact and reusing purified wastewater in various areas due to the water stress that Morocco is currently experiencing.

The town of Skhirat is equipped with a natural lagooning-type sewage treatment plant and activated sludge to manage the discharge of wastewater without polluting the receiving environment.

In fact, the composition of wastewater reflects lifestyles [1]. Pollution is an artificial phenomenon resulting either from concentration of natural substances or from non-natural synthetic compounds (xenobiotics) released to the environment [2]. Organic and inorganic substances released into the environment because of domestic, agricultural and industrial activities lead to organic and inorganic pollution $[3,4]$.

\section{Study area}

The total area of the prefecture is $1052.67 \mathrm{~km}^{2}$ and represent $13 \%$ of the north-west region of which it belongs and $0.13 \%$ of the national area. Our study area is spread over an area of 600 ha according to the city development plan established on June 1999.

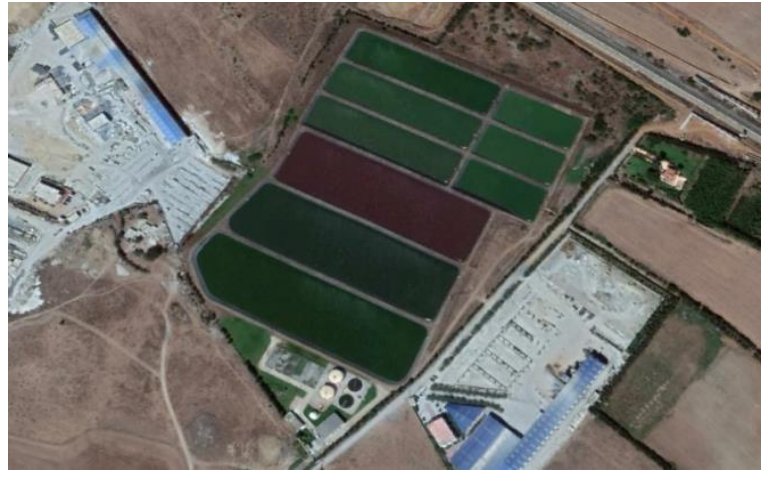

Figure 1: Geographical location of the STEP of the city of Skhirat, Morocco. [5]

\section{Materials and methods}

Sampling was carried out by monthly samples for one year with four samples for each month. In addition, the study sites were selected at the entrance and exit of the STEP of the city Skhirat (Region Rabat-Salé-Kenitra). Subsequently, the conservation of wastewater samples was made according to the general guide for the conservation and handling of the sample [6].

The measurement of SM was carried out by a cellulose membrane filter of $0.45 \mu \mathrm{m}$ diameter [7].

While BOD5 was measured by an oxytop at a temperature of $20^{\circ} \mathrm{c}$ during five days of incubation and COD by a spectrophotometer.

The average discharge of domestic wastewater is calculated based on the average consumption per day in drinking water and the return rate to sewer. 


$$
Q m=\frac{D \times N \times T}{86400}
$$

Qm: Average flow of wastewater in litres per second.

D: Average staffing per day in litres/capita/day.

$\mathrm{N}$ : number of habitants. $\mathrm{N}=$ population density (hab./Ha) * Habitat Area (Ha).

$\mathrm{T}$ : return rate to sewer/

\section{Results and Discussion}

The domestic sewage of the city of Skhirat represents a very large volume of $76673 \mathrm{~m}^{3}$ with an average flow of $2173.5 \mathrm{~m}^{3} /$ day and is characterized by a pollutant load in terms of COD, BOD5 and SM. The ratios of COD/BOD5 and SM/BOD5 are calculated to measure the degree of their biodegradability, study photosynthesis, measure the performance of this station, and to determine whether there have been anomalies within the structures.

\subsection{Characterization of the polluant load of domestic wastewater}

Table 1: Descriptive statistics presentation.

\begin{tabular}{lrrrrr}
\hline \multicolumn{1}{c}{ Variables } & Obs & Minimum & Maximum & Mean & $\begin{array}{r}\text { Standard- } \\
\text { Deviation }\end{array}$ \\
\hline V (mean) & 12 & 63160,00 & 76673,00 & 66473,00 & 3662,01 \\
$\begin{array}{l}\text { Q (mean. } \\
\text { entrance) }\end{array}$ & 12 & 2037,00 & 2473,32 & 2173,5 & 113,41 \\
$\begin{array}{l}\text { BOD }_{5} \\
\text { (entrance) }\end{array}$ & 12 & 141,50 & 477,50 & 306,53 & 102,37 \\
$\begin{array}{l}\text { BOD } \\
\text { (exit) }\end{array}$ & 12 & 12,00 & 46,00 & 29,00 & 11,27 \\
$\begin{array}{l}\text { COD } \\
\text { (entrance) }\end{array}$ & 12 & 328,00 & 1064,00 & 622,11 & 183,27 \\
COD (exit) & 12 & 29,00 & 119,00 & 78,37 & 28,56 \\
$\begin{array}{l}\text { SM } \\
\text { (entrance) }\end{array}$ & 12 & 192,50 & 585,00 & 386,50 & 132,71 \\
$\begin{array}{l}\text { SM (exit) } \\
\text { (12 }\end{array}$ & 24,00 & 200,00 & 79,25 & 49,79 \\
\hline
\end{tabular}

The town of Skhirat generates a significant amount of wastewater and is characterized by concentrations of COD, BOD5 and SM at the entrance to STEP Skhirat, respectively $622.11 \mathrm{mg} / \mathrm{L}, 306.53 \mathrm{mg} / \mathrm{L}$ and 386.50 $\mathrm{mg} / \mathrm{L}$. High BOD5 levels suggest that there is a high level of organic matter [8].

The recorded concentrations of COD (entrance) at $622.11 \mathrm{mg} / \mathrm{L}$, BOD5 (entrance) at $306.53 \mathrm{mg} / \mathrm{l}$, and SM (entrance) at $386.50 \mathrm{mg} / \mathrm{L}$ are higher than those of COD at $514 \mathrm{mg} / \mathrm{L}$, BOD5 at $280 \mathrm{mg} / \mathrm{L}, \mathrm{SM}$ at $275 \mathrm{mg} / \mathrm{L}$, respectively, recorded at the main channel of the City of Oujda [9].

\subsection{STEP purification performance in terms of COD, BOD5 and SM}

The sewage treatment plant of Skhirat provides us with a good performance of the degradation of the organic matter in terms of BOD5, COD and SM respectively in the order of $90.68 \%, 87.4 \%$ and $79.5 \%$.

Table 2: Presentation of monthly reductions in COD, BOD5 and SM.

\begin{tabular}{|l|r|c|c|}
\hline \multicolumn{1}{|c|}{ Month } & $\begin{array}{c}\text { Abatement } \\
\left(\mathrm{BOD}_{5}\right. \\
\text { entrance })\end{array}$ & $\begin{array}{c}\text { Abatement } \\
(\text { CODentrance })\end{array}$ & $\begin{array}{c}\text { Abatement } \\
\text { (SM } \\
\text { entrance })\end{array}$ \\
\hline January & 91,52 & 91,16 & 87,53 \\
\hline February & 91,57 & 89,37 & 84,38 \\
\hline March & 92,13 & 89,89 & 82,95 \\
\hline April & 92,15 & 87,98 & 82,37 \\
\hline May & 91,73 & 88,89 & 87 \\
\hline June & 89,47 & 84,81 & 80,04 \\
\hline July & 91,08 & 83,8 & 75,14 \\
\hline August & 90,37 & 88,82 & 65,81 \\
\hline September & 88,07 & 86,29 & 80,04 \\
\hline October & 89,77 & 86,78 & 81,6 \\
\hline November & 90,73 & 85,21 & 80,33 \\
\hline December & 89,62 & 88,58 & 83,43 \\
\hline Mean & $\mathbf{9 0 , 6 8 \%}$ & $\mathbf{8 7 , 4} \%$ & $\mathbf{7 9 , 5} \%$ \\
\hline
\end{tabular}

As a result, we find that the efficiency of the BOD5 is higher than that of the sewage treatment plant in the city of Oujda by $90 \%$ against the recorded yields of COD and the SM are slightly weak compared to those obtained in the same station of $89 \%, 88 \%$ [10].

\subsection{Ratios of biodegradability COD and BOD5 and confirmation of type of treatment}

The COD/BOD5 ratio provides information on the nature of the pollution and indicates the biodegradability of the pollutants [11]. For a domestically dominant effluent, this ratio is generally between 1.5 and 2.5 and for industrial effluents that may contain a significant fraction of non-biodegradable compounds, then the COD/BOD5 ratio could be considered more or less conducive to biological treatment, the following rules are generally retained:

- $\mathrm{COD} / \mathrm{BOD}_{5}<3$ : Easily biodegradable effluent.

$-2<$ COD/BOD5 $<3$ : Medium biodegradable effluent.

- COD/BOD5 > 3: Effluent that is difficult to be biodegradable or not biodegradable.

This biodegradability index (COD/BOD5) is also very useful for monitoring the efficacy of biological treatments. The higher the ratio, the hardest it is to perform a biological treatment. 
Table 3: Presentation of the ratios COD/BOD5 and SM/BOD5

\begin{tabular}{|l|c|c|}
\hline \multicolumn{1}{|c|}{ Month } & $\begin{array}{c}\mathrm{COD}(\text { entrance }) \\
\mathrm{BOD}_{5}(\text { entrance })\end{array}$ & $\begin{array}{c}\mathrm{SM}(\text { entrance }) / \\
\mathrm{BDO}_{5}(\text { entrance })\end{array}$ \\
\hline January & 2,32 & 1,36 \\
\hline February & 2,59 & 1,26 \\
\hline March & 1,99 & 1,02 \\
\hline April & 1,93 & 1,04 \\
\hline May & 2,49 & 1,38 \\
\hline June & 1,79 & 1,36 \\
\hline July & 1,55 & 1,14 \\
\hline August & 2,23 & 1,23 \\
\hline September & 2,12 & 1,50 \\
\hline October & 1,98 & 1,36 \\
\hline November & 1,91 & 1,21 \\
\hline December & 2,09 & 1,30 \\
\hline Mean & $\mathbf{2 , 0 8}$ & $\mathbf{1 , 2 6}$ \\
\hline
\end{tabular}

We notice that the ratio of COD (input)/BOD5 (input) (2.08) is less than three, which allows us to confirm that these effluents are easily biodegradable. As a result, we can confirm that the biological treatment of the purification plant is still valid and reliable. This ratio is higher than that recorded (1.84) at the main channel of the City of Oujda [9] and is lower than that recorded (2.12) by Rassam [10].

In addition, the average value of the SM/BOD5 ratio obtained for these effluents is 1.26 and is consistent with that of the usual ratio of 1.2 to 1.5 . This ratio is lower than that recorded on the main channel (1.73) in the city of Oujda [9]. When the ratio of SM/BOD5 is high, we are witnessing a significant disturbance at the wastewater level. The suspended matter makes the water disturbed and prevent the penetration of light. This causes a malfunction in the degradation of the organic matter by specific bacteria (photosynthesis phenomenon).

Table 4: Presentation of eigenvalues.

\begin{tabular}{lcc}
\hline & F1 & F2 \\
\hline Own value & 5,62 & 0,20 \\
Variability (\%) & 93,79 & 3,37 \\
\% accrued & 93,79 & $\mathbf{9 7 , 1 7}$ \\
\hline
\end{tabular}

By choosing the first two axes F1 and F2, we notice that both of them contribute to the formations of the main components whose total inertia represents $97.17 \%$ and each brings together a set of variables that correlate between them and their axis.

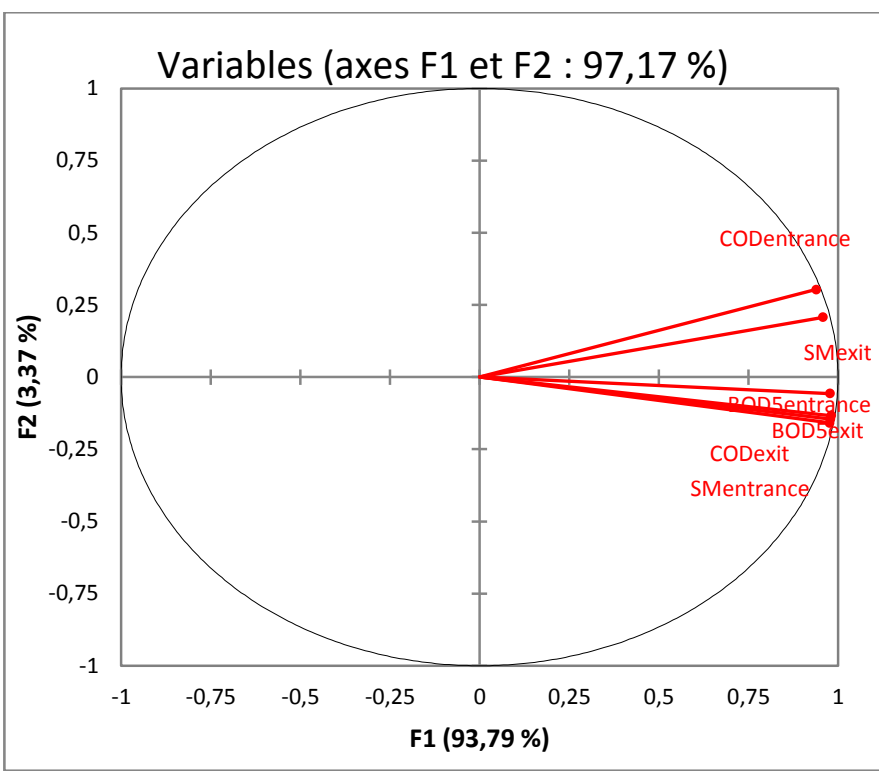

Figure 2: Projection of variables on the factorial plane F1 x F2 $(97.17 \%)$.

At the correlation circle, the SM (entrance), COD (entrance), and BOD5 (entrance) variables are positively correlated on the F1 axis with $93.79 \%$ variability as well as the COD (exit) and BOD5 (exit) SM variables. The two axes $F 1$ and $F 2$ represent a total inertia of $97,17 \%$ of the main component analysis.

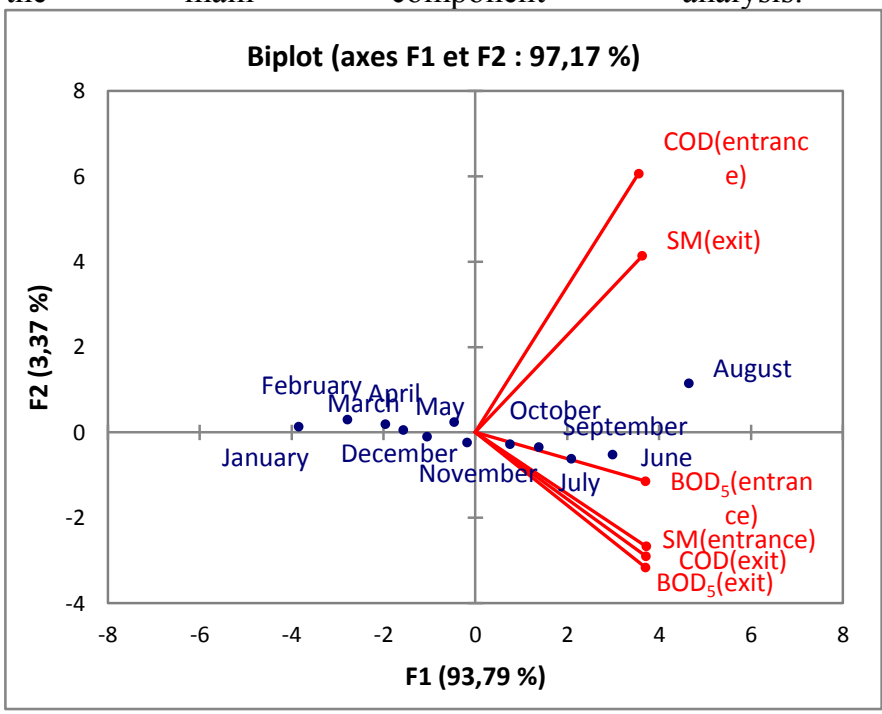

Figure 3: Projection of variables and individuals on the factorial plane F1 x F2 (97.17\%).

At the statistical level, we applied the student T-Test for two paired samples (unilateral right-hand test) :

Table 5: Presentation of Student's T-test results.

$\begin{array}{lc}\text { Difference } & 277,5278 \\ \mathrm{t} \text { (Observed value) } & 8,9143 \\ \mathrm{t} \text { (Critical value) } & 1,7959 \\ \mathrm{DDL} & 11 \\ \text { p-value (unilateral) } & <0,0001 \\ \text { Alpha } & 0,05\end{array}$


To confirm the difference between entry and the exit of the station, we used the Student $\mathrm{T}$ with a P-value inferior to the Risk of error $\alpha=0.05$.

- $\mathbf{H O}$ (null hypothesis): The difference between the mean is 0 .

- Ha (alternative hypothesis): The difference between the mean is greater than 0 .

Since the calculated $\mathrm{P}$-value is less than the significance level alpha $=0.05$, the null hypothesis $\mathrm{H} 0$ is discarded, then the alternative hypothesis Ha is held.

P.S : The risk of rejecting the null hypothesis H0 when True is less than $0.01 \%$.

\section{Conclusion}

Wastewater arriving at the STEP is purified with a better performance in terms of BOD5, COD and SM respectively in the order of $90.68 \%, 87.4 \%$, and $79.5 \%$. We can say that the organic matter is easily biodegradable because the COD/ BOD5 ratio is 2.13. The main component analysis confirm that the process of degradation of organic matter has been successfully completed. This is shown by the results obtained at the exit of the STEP are within the rejection standards.

\section{Acknowledgement}

Acknowledgement to Prof. Azzedine El Midaoui, President of the University Ibn Tofail, Prof. Fatima El Hannouni, Thesis Director at the Kenitra Faculty of Sciences, Prof. Sakina Belhamidi and all who participated in this work.

\section{References}

1. Gray NF., Biology of Wastewater Treatment, Oxford Univ. Press, Oxford (1989).

2. Abdel-Raouf N., Al-Homaidan AA., IBM Ibraheem., Saudi Journal of Biological Sciences Microalgae and wastewater treatment.. Vol 19, 3, pp. 257-275 (2012).

3. Mouchet P., a review Water Res, Algal reactions to mineral and organic micropollutants, ecological consequences and possibilities for industrial scale application, 20, pp. 399-412 (1986).

4. Lim S., Chu W., Phang S, J. Bioresour, Technol. Use of Chlorella vulgaris for bioremediation of textile wastewater, 01, 7314-7322 (2010).

5. Googlemaps, https://www.google.com/maps/ @ $33.8289516,7.087657,590 \mathrm{~m} / \mathrm{data}=! 3 \mathrm{~m} 1 ! 1 \mathrm{e} 3$ (2019).

6. ISO 5667/3, Quality of water - Sampling - a guid for conservation and manipulation of samples, (1994)

7. Rodier J., Natural water analysis, wastewater, sea Water, 8th edition, Denod, Paris, 1383 p. (1996).

8. Karib H., Belemlih A., Shfee M.S., Bahhoun J., Department of Hygiene and foodstuffs industry of Animal origin. Contribution to the bacteriological Study of marine littoral waters in northern Morocco Rabah, Morocco: 22723 (1993).

9. Abouelouafa M., EL Halouani H., Kharboua M., Berrichi A., Acts Inst. Agron. Vet. (Morocco), Physico-Chemical and bacteriological characterization of raw sewage from the city of Oujda: Main Canal and OuedBounaïm. Vol. 22 (3) 143-150 (2002).

10. Rassam A., Chaki A., Bourkhiss B., Bourkhiss M., Bul Soc. R Sci Liège, Performance of degradation of organic matter by lagooning aerated in the sewage treatment plant of the city of Oujda (eastern Morocco). Vol. 81, 121-125 (2012).

11. Rodier J., Water analysis. 9th Edition, Dunod, Paris. 1529 p. (2009). 